Revue d'histoire du XIXe siècle

Société d'histoire de la révolution de 1848 et des

révolutions du XIXe siècle

43 | 2011

L'ordre électoral : savoirs et pratiques

\title{
La Revue blanche. 1871, enquête sur la Commune, introduction et notes de Jean Baronnet, Paris, Les Éditions de l'Amateur, 2011, 205 p. ISBN :
} 978-2-85917-514-6. 17 euros.

Jean-Claude Caron

\section{(2) OpenEdition}

Journals

Édition électronique

URL : http://journals.openedition.org/rh19/4185

DOI : $10.4000 /$ rh19.4185

ISSN : $1777-5329$

Éditeur

La Société de 1848

\section{Édition imprimée}

Date de publication : 13 novembre 2011

Pagination : 169

ISSN : 1265-1354

\section{Référence électronique}

Jean-Claude Caron, " La Revue blanche. 1871, enquête sur la Commune, introduction et notes de Jean Baronnet, Paris, Les Éditions de l'Amateur, 2011, 205 p. ISBN : 978-2-85917-514-6. 17 euros. », Revue d'histoire du XIXe siècle [En ligne], 43 | 2011, mis en ligne le 13 juillet 2012, consulté le 22 septembre 2020. URL : http://journals.openedition.org/rh19/4185; DOI : https://doi.org/10.4000/ rh19.4185

Ce document a été généré automatiquement le 22 septembre 2020.

Tous droits réservés 
La Revue blanche. 1871, enquête sur la Commune, introduction et notes de Jean Baronnet, Paris, Les Éditions de l'Amateur, 2011, 205 p. ISBN : 978-2-85917-514-6. 17 euros.

\author{
Jean-Claude Caron
}

Cette réédition mérite d'être signalée car elle met à la portée du public le résultat d'une enquête menée vingt-six ans après la Commune par une revue de sensibilité anarchiste, la Revue blanche, dont le maître d'œuvre est Félix Fénéon. Trois questions sont proposées à un ensemble de personnalités: leur rôle entre mars et mai 1871; leur opinion sur ce mouvement insurrectionnel et son organisation parlementaire, militaire, financière, administrative; leur opinion sur l'influence de la Commune relativement au mouvement des idées. Ce recueil reprend les 46 réponses reçues - y compris les plus lapidaires, pour dire un refus de répondre. Le déséquilibre - qui n'était pas volontaire au départ - est patent à l'arrivée: les partisans de la Commune l'emportent de loin sur ses adversaires. Trois catégories de personnalités sont isolées : les publicistes (dont Rochefort, Allemane, Jean Grave, Lissagaray, Ernest Daudet, Georges Renard, etc.) ; les anciens membres de la Commune (parmi lesquels Vaillant, Lefrançais, Clément, Ranc, Vésinier, etc.) ; les " autres témoins ", aussi variés que Da Costa, Pilotell, Louise Michel, Louis Andrieux, Nadar, Galliffet, etc., et même un anonyme "insurgé lyonnais ». Cette enquête intéressera aussi bien l'historien de la Commune que celui des représentations, de la mémoire ou de la construction de l'événement. 